\title{
Medieval Scotland
}

Crown, Lordship and Community 



\section{Medieval Scotland \\ Crown, Lordship and Community}

Essays presented to

G.W.S. Barrow

edited by

ALEXANDER GRANT and KEITH J. STRINGER 
() the Editors and the Contributors severally, 1993, 1998

Reprinted in paperback 1998

Edinburgh University Press Ltd

22 George Square, Edinburgh

Typeset in 10/12 CGTimes

at Lancaster University, and

printed in Great Britain by

CPI Antony Rowe, Eastbourne.

Transferred to digital print 2008

A CIP record of this book is available from the British Library

ISBN $074861110 \mathrm{X}$

The right of the Contributors

to be identified as authors of this work

has been asserted in accordance with

the Copyright, Designs and Patents Act 1988. 